\title{
ANALIZA I OCENA ROZWOJU BANKOWOŚCI SPÓŁDZIELCZEJ W POLSCE I WYBRANYCH KRAJACH EUROPEJSKICH W LATACH 2007-2012
}

\begin{abstract}
Cele pracy stanowiły poznanie i ocena zmian w rozwoju działalności wybranych bankowych grup spółdzielczych w Europie w latach 2007-2012. W pracy wykorzystano dane dotyczące wybranych 26 bankowych grup spółdzielczych w Europie ( 25 z krajów UE i 1 ze Szwajcarii), które należały do Europejskiego Stowarzyszenia Banków Spółdzielczych (EACB). Rozwój bankowości spółdzielczej, który można rozpatrywać z punktu widzenia organizacyjnego i finansowego, był zróżnicowany w poszczególnych krajach. Ogólnie w całej UE nastąpił rozwój organizacyjny tego sektora, na co wskazuje rosnąca liczba placówek banków, ich członków i klientów oraz zatrudnionych osób. Banki spółdzielcze wzmacniały swoją pozycję finansową, ponieważ wzrosła wartość posiadanego przez nie majątku, w tym udzielanych przez nie kredytów oraz przyjmowanych depozytów. Praktycznie we wszystkich bankowych grupach efektywność wykorzystania majątku mierzona jego rentownością (ROA) była dość niska, nieprzekraczająca 1\%. W 2012 r. trzy grupy odnotowały deficytowość. Rentowność kapitału własnego (ROE) wahała się od kilku do kilkunastu procent. Tylko w trzech krajach wzrosły wartości obu wskaźników rentowności. Poprawa wskaźnika kosztów do dochodów w latach 2007-2012 nastąpiła tylko w kilku analizowanych krajach. Wartość współczynnika wypłacalności w 2012 r. w większości grup bankowych była na poziomie wymaganym przez prawo (8\%). Za pozytywne należy uznać, że tylko kilka grup bankowych w okresie 2007-2012 zanotowała spadek (i to niewielki) tego wskaźnika.
\end{abstract}

Słowa kluczowe: banki spółdzielcze, rentowność, wypłacalność

\section{WPROWADZENIE}

Banki spółdzielcze często są oceniane przez agencje ratingowe jako instytucje bardziej stabilne, szczególnie w okresie kryzysu finansowego, niż duże banki komercyjne ${ }^{3}$. Dzięki temu, że nie koncentrują się na agresywnych działaniach zmierzających do maksymalizacji zysku i wzrostu wartości rynkowej banku w krótkim okresie, stabilizują system finansowy swoich krajów. Do charakterystycznych cech banków spółdzielczych można zaliczyć wysoką relację funduszy własnych do aktywów ważonych ryzykiem, stabilność dochodów i zdecentralizowaną strukturę decyzyjną, co stanowi podstawę racjonalnego

\footnotetext{
${ }^{1}$ Dr hab. Jan Zuba, Prof. Uniwersytetu Przyrodniczego, Katedra Zarządzania i Marketingu, Uniwersytet Przyrodniczy w Lublinie, ul. Akademicka 13, 20-950 Lublin, e-mail: jan.zuba@up.lublin.pl, tel.: 814610061 w.159 (autor korespondencyjny)

${ }^{2}$ Dr hab. inż. Stanisław Gędek, Prof. Politechniki Rzeszowskiej, Katedra Ekonomii, Politechnika Rzeszowska, Al. Powstańców Warszawy 8, 35-959 Rzeszów, e-mail: gedeks @ prz.edu.pl, tel.: 178651085

${ }^{3} \mathrm{~V}$. McCarroll, S. Habberfield, The outlook for co-operative banking in Europe 2012. Banking on values, building on agility, Oliver Wyman Report, http://www.oliverwyman.com/the-outlook-for-cooperative-banking-ineurope-2012.htm\#.UeaGTW0SqZR (dostęp: 20.04.2015), s. 23-24.
} 
i aktywnego zarządzania ryzykiem bankowym. W bankach tych w mniejszym stopniu niż w bankach komercyjnych istnieją: problem asymetrii informacji, niebezpieczeństwo wystąpienia zjawiska moral hazard i błędnej selekcji wniosków kredytowych. Sprzyja to kształtowaniu się optymalnej struktury portfela kredytowego ${ }^{4}$.

Banki spółdzielcze dzięki temu, że działają na zasadzie spółdzielni, są podmiotami ekonomii społecznej, realizują więc zasadę, że oprócz celu ekonomicznego istotna jest także misja społeczna ${ }^{5}$. Prowadzona przez nie polityka sprzyja: spójności społecznej, zwiększaniu zatrudnienia, walce przeciwko biedzie, demokracji, lepszemu zarządzaniu oraz stabilnemu rozwojowi ${ }^{6}$. Poprzez kredytowanie, w tym małych i średnich przedsiębiorstw, odgrywają one kluczową rolę w rozwoju regionalnym i lokalnym, wspierając spójność gospodarczą tych obszarów ${ }^{7}$.

Wpływ na silną pozycję bankowości spółdzielczej w Europie, poza wielowiekową tradycją funkcjonowania, mają zasady spółdzielcze - między innymi otwarte członkostwo, demokratyczny nadzór ze strony członków, ekonomiczne uczestnictwo, troska o społeczeństwo, samorządność i niezależność, kooperacja między bankami spółdzielczymi, subsydiarność, regionalizacja działania ${ }^{8}$. Banki spółdzielcze są własnością lub współwłasnością lokalnej społeczności, a ich funkcjonowanie opiera się na zaufaniu ze strony tej społeczności, znajomości jej potrzeb finansowych i doświadczeniu w ich zaspokajaniu9. Zakres działalności kredytowej banków spółdzielczych w Europie jest istotny, szczególnie $\mathrm{w}$ finansowaniu potrzeb przedsiębiorstw $\mathrm{z}$ grupy $\mathrm{MSP}^{10}$.

Rozwój działalności każdego banku, w tym spółdzielczego, opiera się na pośrednictwie finansowym: przyjmowaniu depozytów oraz udzielaniu kredytów. Aktywność ta jest kluczowa dla sprawnego funkcjonowania gospodarki ${ }^{11}$. Banki przeprowadzają operacje przy użyciu swoich aktywów. Podstawowym kryterium oceny tych operacji jest ich dochodowość. Największe dochody dla banku przynoszą kredyty. Kredyty zawsze, poza

\footnotetext{
${ }^{4}$ A. Szelągowska, Wspótczesna bankowość spótdzielcza, CeDeWu, Warszawa 2012, s. 55-63.

${ }^{5}$ M. Golec, Społeczne uwarunkowania działalności banków spółdzielczych, [w:] Banki spółdzielcze w Polsce w warunkach kryzysu finansowego i gospodarczego, red. M. Stefański, WSH-E, Włocławek 2010, s. 66.

${ }^{6}$ P. Dziekański, Banki spółdzielcze inkubatorami lokalnej przedsiębiorczości, [w:] Bank spółdzielczy gwarantem stabilizacji i bezpieczeństwa lokalnego systemu finansowego, red. A. Pawlik, P. Dziekański, Uniwersytet Jana Kochanowskiego, Kielce 2012, s. 98.

${ }^{7}$ T. Siudek, Wpływ działalności kredytowej banków spótdzielczych na lokalny rozwój spoteczno-gospodarczy w Polsce[w:] Bank spótdzielczy gwarantem stabilizacji i bezpieczeństwa lokalnego systemu finansowego, red. A. Pawlik, P. Dziekański, Uniwersytet Jana Kochanowskiego, Kielce 2012, s. 64.

${ }^{8}$ A. Gospodarowicz, Funkcjonowanie spółdzielczych grup bankowych w Polsce $i$ wybranych krajach europejskich, Wydawnictwo Uniwersytetu Ekonomicznego we Wrocławiu, Wrocław 2008, s. 14; A. Magdoń, Systemic and structural transformations of cooperative banking in Poland, Wydawnictwo Katolickiego Uniwersytetu Lubelskiego Jana Pawła II, Stalowa Wola 2009, s. 164.; J. Szambelańczyk, Banki spółdzielcze w Polsce w procesach zmian systemowych, Wydawnictwo Akademii Ekonomicznej w Poznaniu, Poznań 2006, s. 90; M. Szyszko Banki spótdzielcze, [w:] Pośrednictwo finansowe, red. W. Przybylska-Kapuścińska, CeDeWu, Warszawa 2009, s. 76.

${ }^{9}$ R. Kata, Rola banków spółdzielczych w finansowaniu rolnictwa regionu podkarpackiego, FOSZE, Rzeszów 2003, s. 79.

${ }^{10}$ M. Zuba, Zmiany działalności kredytowej banków spótdzielczych w Polsce $i$ w Europie w latach 2007-2011, „Zeszyty Naukowe SGGW w Warszawie, Ekonomika i Organizacja Gospodarki żywnościowej” 2013/103, s. 103

${ }^{11}$ E. Miklaszewska, Bank na rynku finansowym. Problemy skali, efektywności i nadzoru, Wolters Kluwer, Warszawa 2010, s. 17.
} 
okresami wojen czy recesji, stanowiły podstawę finansową systemu bankowego i zapewniały największe zyski ${ }^{12}$.

Cele pracy stanowiły poznanie i ocena zmian w rozwoju działalności wybranych bankowych grup spółdzielczych w Europie w latach 2007-2012, a więc w trudnym dla systemu bankowego czasie, ponieważ po rozpoczęciu kryzysu finansowego. W pracy wykorzystano dane dotyczące wybranych 26 bankowych grup spółdzielczych w Europie (25 z krajów UE i 1 ze Szwajcarii), które były członkami Europejskiego Stowarzyszenia Banków Spółdzielczych (EACB, European Association of Co-operative Banks). Rozwój bankowości spółdzielczej można rozpatrywać z punktu widzenia organizacyjnego i finansowego. Rozwój organizacyjny wybranych grup bankowych scharakteryzowano poprzez liczbę placówek, członków i klientów banków oraz zatrudnionych osób. Rozwój finansowy banków determinowany jest wartością posiadanych aktywów, udzielonych kredytów oraz przyjętych depozytów. Oceniono więc te pozycje bilansowe, a także udział badanych grup w rynku depozytów i kredytów. Zanalizowano osiąganą przez banki rentowność (majątku, kapitału własnego) i wypłacalność, które decydują o ich sytuacji finansowej. W pracy wykorzystano bazę danych EACB dla lat 2007-2012. Zastosowano w niej wybrany zestaw metod analizy opisowej, porównawczej i graficznej oraz syntezy.

\section{ROZWÓJ ORGANIZACYJNY}

Sektor bankowości spółdzielczej w Europie w latach 2007-2012 był sprawnie rozwinięty. Przy spadku liczby banków spółdzielczych o ponad 10\% do 3716 liczba placówek bankowych poszczególnych grup spółdzielczych zwiększyła się o $13 \%$ do prawie 71 tys. (tab. 1).

Tabela 1. Liczba banków zrzeszonych i placówek bankowych wybranych grup spółdzielczych w Europie w latach 2007-2012

\begin{tabular}{|l|c|c|l|l|l|l|l|}
\hline \multirow{2}{*}{ Grupa spółdzielcza } & \multirow{2}{*}{$\begin{array}{c}\mathrm{Nr} \\
\text { grupy }\end{array}$} & \multicolumn{3}{|c|}{ Banki zrzeszone } & \multicolumn{3}{c|}{ Placówki bankowe } \\
\cline { 5 - 8 } & & 2007 & 2010 & 2012 & 2007 & 2010 & 2012 \\
\hline $\begin{array}{l}\text { Osterreichische Raiffeisenbanken } \\
\text { (Austria) }\end{array}$ & 1 & 548 & 551 & 527 & 1746 & 1738 & 1758 \\
\hline $\begin{array}{l}\text { Osterreichischer Genossenscha- } \\
\text { ftsverband (Austria) }\end{array}$ & 2 & 80 & 80 & 64 & 1054 & 1042 & 525 \\
\hline $\begin{array}{l}\text { Central Co-operative Bank } \\
\text { (Bułgaria) }\end{array}$ & 3 & - & 30 & 30 & 251 & 266 & 271 \\
\hline Co-operative Central Bank (Cypr) & 4 & 119 & 111 & 97 & 470 & 426 & 420 \\
\hline $\begin{array}{l}\text { Sammenslutningen Danske An- } \\
\text { delskasser/Nykredit (Dania) }\end{array}$ & 5 & 23 & 16 & 1 & 80 & 51 & - \\
\hline $\begin{array}{l}\text { OKOBANK/OP-Pohjola Group } \\
\text { (Finlandia) }\end{array}$ & 6 & 229 & 213 & 197 & 630 & 554 & 519 \\
\hline Credit Agricole (Francja) & 7 & 39 & 39 & 39 & 11000 & 11500 & 11300 \\
\hline Credit Mutuel (Francja) & 8 & 18 & 18 & 18 & 5149 & 5875 & 5961 \\
\hline Banques Populaires (Francja) & $9 *$ & 20 & 20 & 36 & 2938 & 2938 & 8000 \\
\hline BVR/DZ BANK (Niemcy) & 10 & 1232 & 1138 & 1101 & 13625 & 13474 & 13211 \\
\hline $\begin{array}{l}\text { Association of Cooperative Banks } \\
\text { of Greece (Grecja) }\end{array}$ & 11 & 15 & 16 & 13 & 104 & 191 & 162 \\
\hline $\begin{array}{l}\text { National Federation of Savings } \\
\text { Co-operatives (Węgry) }\end{array}$ & 12 & 143 & 112 & 105 & 1599 & 1520 & 1484 \\
\hline
\end{tabular}

${ }^{12}$ Z. Dobosiewicz, Bankowość, PWE, Warszawa 2011, s. 163. 


\begin{tabular}{|l|l|l|l|l|l|l|l|}
\hline $\begin{array}{l}\text { Assoc. Nazionale fra le Banche } \\
\text { Popolari (Włochy) }\end{array}$ & 13 & 97 & 100 & 100 & 8988 & 9514 & 9514 \\
\hline FEDERCASSE (Włochy) & 14 & 442 & 415 & 394 & 3926 & 4375 & 4448 \\
\hline Banque Raiffeisen (Luxemburg) & 15 & 13 & 13 & 13 & 51 & 49 & 48 \\
\hline $\begin{array}{l}\text { Association of Lithuanian credit } \\
\text { unions (Litwa) }\end{array}$ & 16 & 59 & 61 & 63 & 152 & 167 & 122 \\
\hline Rabobank Nederland (Holandia) & 17 & 174 & 141 & 136 & 1159 & 911 & 826 \\
\hline $\begin{array}{l}\text { Krajowy Związek Banków Spół- } \\
\text { dzielczych (Polska) }\end{array}$ & 18 & 584 & 576 & 572 & 4021 & 4395 & 4193 \\
\hline $\begin{array}{l}\text { FENACAM/Credito Agricola } \\
\text { Portugalia) }\end{array}$ & 19 & 100 & 86 & 84 & 627 & 691 & 686 \\
\hline Creditcoop (Rumunia) & 20 & 124 & 48 & 47 & - & 784 & 779 \\
\hline $\begin{array}{l}\text { Dezelna Banka Slovenije d.d. } \\
\text { (Słowenia) }\end{array}$ & 21 & 1 & - & 1 & 1 & 88 & 85 \\
\hline $\begin{array}{l}\text { Union Nacional de Cooperativas } \\
\text { de Credito (Hiszpania) }\end{array}$ & 22 & 82 & 80 & 68 & 5006 & 5079 & 4832 \\
\hline Landshypotek (Szwecja) & 23 & 10 & 10 & 10 & - & - & - \\
\hline $\begin{array}{l}\text { The Co-operative Bank (Wielka } \\
\text { Brytania) }\end{array}$ & 24 & - & - & - & 90 & 342 & 340 \\
\hline TOTAL (EU 27) & 25 & 4162 & 3874 & 3716 & 62829 & 65970 & 70967 \\
\hline $\begin{array}{l}\text { Schweizer Verband der Raiffei- } \\
\text { senbanken/Raiffeisen Schweiz } \\
\text { (Szwajcaria) }\end{array}$ & 26 & 390 & - & 321 & 1155 & - & 1084 \\
\hline
\end{tabular}

- brak danych; * po fuzji Banques Populaire z Caisse D’Epargne w 2011 r. - BPCE

Źródło: opracowanie własne na podstawie danych EACB: Key Statistics of European Association of Co-operative Banks (EACB) [2015], http://www.eacb.coop/en/home.html (dostęp: 20.04.2015).

Długa, nawet kilkusetletnia, tradycja rozwoju spółdzielczości bankowej w danym kraju wpływa na to, że należy on do grupy państw o dużej liczbie banków spółdzielczych. W 2012 r. do tej grupy należały: Niemcy (1101), Austria (591), Polska (572), Włochy (494) i Szwajcaria (321). Tylko w kilku badanych grupach spółdzielczych wzrosła liczba zrzeszonych banków (w Banques Populaires o 16 banków, w Assoc. Nazionale fra le Banche Popolari o 3, w Association of Lithuanian credit unions o 4). Natomiast wzrost placówek bankowych wystąpił w wielu krajach, w tych o gęstej sieci placówek liczącej kilka tysięcy oddziałów (we Francji, w Polsce, we Włoszech), jak i słabiej rozwiniętej, mającej od kilkudziesięciu do kilkuset oddziałów (w Bułgarii, Grecji, Portugali, Słowenii). 
Tabela 2. Liczba członków spółdzielni, ich klientów i zatrudnionych w wybranych bankowych grupach spółdzielczych w Europie w latach 2007-2012 (tys.)

\begin{tabular}{|c|c|c|c|c|c|c|c|c|c|}
\hline \multirow{2}{*}{ Nr grupy } & \multicolumn{3}{|c|}{ Członkowie (tys.) } & \multicolumn{3}{|c|}{ Klienci (tys.) } & \multicolumn{3}{|c|}{ Zatrudnienie (tys.) } \\
\cline { 2 - 12 } & 2007 & 2010 & 2012 & 2007 & 2010 & 2012 & 2007 & 2010 & 2012 \\
\hline 1 & 1700 & 1720 & 1720 & 3600 & 3600 & 3600 & 32 & 26 & 30 \\
\hline 2 & 674 & 702 & 688 & 1500 & 1500 & 900 & 14 & 13 & 6 \\
\hline 3 & 6 & 7 & 7 & 881 & 1221 & 1393 & 2 & 2 & 2 \\
\hline 4 & 535 & 634 & 622 & 600 & 747 & 989 & 2 & 3 & 3 \\
\hline 5 & 64 & 63 & 291 & 122 & 125 & 1092 & 0,6 & 1 & 4 \\
\hline 6 & 1202 & 1300 & 1371 & 4086 & 4133 & 4210 & 12 & 13 & 12 \\
\hline 7 & 6000 & 6500 & 7000 & 44000 & 54000 & 51000 & 163 & 161 & 150 \\
\hline 8 & 7100 & 7200 & 7400 & 14900 & 29200 & 30100 & 59 & 76 & 79 \\
\hline 9 & 3300 & 3300 & 8100 & 7800 & 7800 & 36000 & 41 & 41 & 117 \\
\hline 10 & 16100 & 16689 & 17300 & 30000 & 30000 & 30000 & 187 & 187 & 190 \\
\hline 11 & 176 & 212 & 189 & 176 & 431 & 396 & 1 & 1 & 1 \\
\hline 12 & 250 & 121 & 84 & 1100 & 1100 & 1150 & 8 & 7 & 7 \\
\hline 13 & 1022 & 1213 & 1213 & 9150 & 9593 & 9593 & 80 & 85 & 85 \\
\hline 14 & 885 & 1011 & 1135 & 5100 & 5700 & 6000 & 29 & 32 & 32 \\
\hline 15 & 5 & 8 & 8 & 100 & 125 & 127 & 0,5 & 1 & 1 \\
\hline 16 & 81 & 102 & 136 & 82 & 102 & 136 & 0,4 & 0,5 & 1 \\
\hline 17 & 1638 & 1801 & 1918 & 9000 & 10000 & 10000 & 55 & 59 & 60 \\
\hline 18 & 2500 & 2500 & 1052 & 10500 & 7500 & 10000 & 30 & 32 & 33 \\
\hline 19 & 285 & 392 & 389 & 1889 & 1181 & 1138 & 4 & 4 & 4 \\
\hline 20 & 760 & 680 & 668 & 1104 & 1086 & 1098 & 3 & 2 & 2 \\
\hline 21 & 0,4 & 0,3 & 0,3 & 85 & 86 & 84 & 0,4 & 0,4 & 0,4 \\
\hline 22 & 2008 & 2224 & 2555 & 10347 & 10820 & 10958 & 20 & 21 & 20 \\
\hline 23 & 58 & 58 & 58 & 69 & 69 & 69 & 0,1 & 0,1 & 0,1 \\
\hline 24 & 3000 & 2005 & 2000 & 2560 & 5111 & 4700 & 3 & 11 & 9 \\
\hline 25 & 4934850438 & 55904 & 158750 & 181101 & 214735 & 747 & 777 & 847 \\
\hline 26 & 1371 & - & 1795 & 3000 & - & 3645 & 8 & - & 11 \\
\hline brak danych & & & & & & & \\
\hline
\end{tabular}

Źródło: opracowanie własne na podstawie danych EACB: Key Statistics of European Association of Co-operative Banks (EACB) [2015], http://www.eacb.coop/en/home.html (dostęp: 20.04.2015).

W latach 2007-2012 w UE liczba członków banków spółdzielczych wzrosła o 13\% (z 49,3 do 55,9 mln osób) przy zdecydowanie większym tempie wzrostu (35\%) liczby klientów tych banków (z 158,8 do 214,7 mln osób). Zmniejszenie liczby członków banków spółdzielczych nastąpiło na Węgrzech, w Polsce, Wielkiej Brytanii, Rumunii i Słowenii (tab. 2). W niektórych z tych krajów (w Polsce, Rumunii, Słowenii), a także w Austrii i Portugalii spadła również liczba klientów tych banków. Do krajów o najwyższej w Europie w 2012 r. liczbie klientów banków spółdzielczych można zaliczyć Francję (117 mln), Niemcy (30 mln), Włochy $(16 \mathrm{mln})$, Hiszpanię $(11 \mathrm{mln})$ i Polskę $(10 \mathrm{mln})$. 
W 2012 r. w każdym z krajów (poza Litwą) liczba klientów banków spółdzielczych przewyższała liczbę ich członków, nawet kilkanaście (Węgry, Luksemburg) czy kilkaset razy (Bułgaria i Słowenia), co wynikało z niewielkiej liczby członków banków spółdzielczych w tych krajach. W 2007 r. na Litwie oraz w Grecji i Wielkiej Brytanii nie wszyscy członkowie banków spółdzielczych byli ich klientami. W UE, w tym w większości krajów, w latach 2007-2012 zatrudnienie w omawianym sektorze wzrosło (ogółem o 13\% do 847 tys. osób). Tylko na Francję przypada 40\% zatrudnionych (346 tys.). Największe tempo wzrostu zatrudnienia odnotowano w Wielkiej Brytanii, szczególnie w 2010 r. Można je tłumaczyć utratą zaufania przez obywateli tego kraju do banków komercyjnych i zwróceniem się do banków spółdzielczych oraz w konsekwencji wzrostem w nich zatrudnienia.

\section{ROZWÓJ FINANSOWY}

Bankowość spółdzielcza w Europie ma dość stabilne podstawy zasobowe dla swojego rozwoju. W latach 2007-2012 wartość jej aktywów wzrosła o 42\% do 7,33 bln euro (tab. 3). Aktywa bankowości spółdzielczej Francji, Niemiec, Holandii, Włoch i Austrii stanowiły w 2012 r. $91 \%$ zasobów majątkowych w UE, podczas gdy w 2007 r. - 95\%.

Tabela 3. Wartość aktywów banków, posiadanych depozytów oraz udzielonych kredytów i pożyczek przez wybrane bankowe grupy spółdzielcze w Europie w latach 2007-2012

\begin{tabular}{|c|c|c|c|c|c|c|c|c|c|c|c|c|}
\hline \multirow{2}{*}{$\begin{array}{l}\mathrm{Nr} \\
\mathrm{gr}\end{array}$} & \multicolumn{3}{|c|}{ Aktywa (mld euro) } & \multicolumn{3}{|c|}{ Depozyty (mld euro) } & \multicolumn{3}{|c|}{ Kredyty (mld euro) } & \multicolumn{3}{|c|}{$\begin{array}{c}\text { Relacja } \\
\text { Depozyty/kredyty }\end{array}$} \\
\hline & 2007 & 2010 & 2012 & 2007 & 2010 & 2012 & 2007 & 2010 & 2012 & 2007 & 2010 & 2012 \\
\hline 1 & 236,26 & 255,22 & 291,54 & 132,05 & 149,74 & 172,20 & 144,91 & 162,78 & 193,88 & 0,91 & 0,92 & 0,89 \\
\hline 2 & 94,57 & 65,17 & 57,41 & 62,67 & 29,59 & 11,79 & 52,77 & 45,02 & 27,98 & 1,19 & 0,66 & 0,42 \\
\hline 3 & 0,80 & 1,17 & 1,71 & 0,68 & 0,99 & 1,47 & 0,34 & 0,61 & 0,85 & 2,03 & 1,62 & 1,73 \\
\hline 4 & 9,74 & 19,94 & 21,17 & 9,05 & 13,51 & 15,17 & 6,76 & 12,52 & 13,92 & 1,34 & 1,08 & 1,09 \\
\hline 5 & 1,77 & 2,04 & - & 1,29 & 1,33 & - & 1,15 & 1,28 & - & 1,12 & 1,04 & - \\
\hline 6 & 65,72 & 83,97 & 99,77 & 31,22 & 39,21 & 49,65 & 44,78 & 56,83 & 65,16 & 0,70 & 0,69 & 0,76 \\
\hline 7 & 1540,86 & 1730,85 & 2008,15 & 485,14 & 811,80 & 812,10 & 643,10 & 882,04 & 876,10 & 0,75 & 0,92 & 0,93 \\
\hline 8 & 553,30 & 591,31 & 645,22 & 469,00 & 228,41 & 640,05 & 258,60 & 323,07 & 343,22 & 1,81 & 0,71 & 1,86 \\
\hline 9 & 349,00 & 349,00 & 1138,00 & 167,90 & 167,90 & 537,70 & 122,70 & 122,70 & 583,10 & 1,37 & 1,37 & 0,92 \\
\hline 10 & 994,95 & 1020,31 & 1090,34 & 573,77 & 619,99 & 664,84 & 514,80 & 583,33 & 632,45 & 1,11 & 1,06 & 1,05 \\
\hline 11 & 2,57 & 4,50 & 3,61 & 2,14 & 3,40 & 2,93 & 2,00 & 3,50 & 3,26 & 1,07 & 0,97 & 0,90 \\
\hline 12 & 5,04 & 5,08 & 6,39 & 4,32 & 4,24 & 4,37 & 2,23 & 2,07 & 2,71 & 1,93 & 2,05 & 1,61 \\
\hline 13 & 409,40 & 481,47 & 481,47 & 220,90 & 425,38 & 425,38 & 319,20 & 378,39 & 378,39 & 0,69 & 1,12 & 1,12 \\
\hline 14 & 150,44 & 179,96 & 201,50 & 121,42 & 151,04 & 139,36 & 105,72 & 135,30 & 153,74 & 1,15 & 1,12 & 0,91 \\
\hline 15 & 4,07 & 5,87 & 6,29 & 3,42 & 4,70 & 5,65 & 2,00 & 3,75 & 4,46 & 1,71 & 1,25 & 1,27 \\
\hline 16 & 0,19 & 0,32 & 0,48 & 0,15 & 0,26 & 0,41 & 0,13 & 0,17 & 0,28 & 1,13 & 1,50 & 1,44 \\
\hline 17 & 570,50 & 652,54 & 752,41 & 249,52 & 298,76 & 334,27 & 355,97 & 436,29 & 458,09 & 0,70 & 0,68 & 0,73 \\
\hline 18 & 13,32 & 17,63 & 21,00 & 10,74 & 13,40 & 18,00 & 8,15 & 9,90 & 17,00 & 1,32 & 1,35 & 1,06 \\
\hline 19 & 10,57 & 13,21 & 13,75 & 9,16 & 9,99 & 10,18 & 7,19 & 8,61 & 8,37 & 1,27 & 1,16 & 1,22 \\
\hline 20 & 0,16 & 0,19 & 0,19 & 0,03 & 0,12 & 0,13 & 0,04 & 0,12 & 0,12 & 0,65 & 0,97 & 1,02 \\
\hline 21 & 0,76 & 0,91 & 0,89 & 0,63 & 0,63 & 0,81 & 0,53 & 0,64 & 0,50 & 1,19 & 0,97 & 1,60 \\
\hline 22 & 108,43 & 119,46 & 131,65 & 91,29 & 98,22 & 90,96 & 89,91 & 95,59 & 89,68 & 1,02 & 1,03 & 1,01 \\
\hline 23 & 4,65 & 4,65 & 4,65 & - & - & - & 4,12 & 4,12 & 4,12 & 0,00 & 0,00 & 0,00 \\
\hline 24 & 17,33 & 51,76 & 61,12 & 13,98 & 38,72 & 45,34 & 11,93 & 39,70 & 41,10 & 1,17 & 0,98 & 1,10 \\
\hline 25 & 5150,22 & 5656,49 & 7326,06 & 2689,31 & 3111,31 & 4073,85 & 2741,16 & 3308,32 & 4045,69 & 0,98 & 0,94 & 1,01 \\
\hline 26 & 69,31 & - & 141,03 & 37,88 & - & 111,61 & 57,83 & - & 120,60 & 0,66 & - & 0,93 \\
\hline
\end{tabular}

- brak danych

Źródło: opracowanie własne na podstawie danych EACB: Key Statistics of European Association of Co-operative Banks (EACB) [2015], http://www.eacb.coop/en/home.html (dostęp: 20.04.2015). 
Banki spółdzielcze w Europie w latach 2007-2012 zwiększyły akcję kredytową. Wartość udzielonych kredytów wzrosła ogółem o 48\% do 4,0 bln euro. Było to możliwe dzięki równie dynamicznemu wzrostowi wartości depozytów (ogółem o 51\% do 4,1 bln euro). Większość bankowych grup spółdzielczych zwiększyła wartość depozytów i kredytów. Wartość przyjętych depozytów w bankach Francji, Niemiec, Austrii, Włoch i Holandii wzrosła z 2,5 do 3,7 bln euro (ich łączny udział utrzymał się na poziomie 92\% depozytów w skali UE). Porównywalnie wzrosła wartość kredytów udzielonych w tych krajach z 2,5 do 3,6 bln euro (a ich udział spadł z 92\% do 90\%). W dziewięciu analizowanych grupach relacja depozytów do kredytów nie przekraczała w 2012 r. poziomu jeden, co oznacza, że banki z tych grup udzieliły kredytów na większą wartość niż przyjęte depozyty. W pięciu z tych grup wspomniane zjawisko po czterech latach się nasiliło. W 2012 r. nadwyżka wartości depozytów nad kredytami dotyczyła: Bułgarii, Cypru, Credit Mutuel z Francji, Niemiec, Węgier, Assoc. Nazionale fra le Banche Popolari z Włoch, Luksemburga, Litwy, Polski, Portugalii, Rumunii, Słowenii, Hiszpanii, Wielkiej Brytanii. Banki spółdzielcze w tych krajach prowadziły politykę ostrożnego transferu depozytów w kredyty. Większość z nich (poza Rumunią i grupą włoską), a także Dania, Grecja, Banques Populaires z Francji, Osterreichischer Genossenschaftsverband z Austrii realizowały podobną politykę w 2007 r.

W 2010 r. udział w europejskim rynku kredytów udzielonych przez banki spółdzielcze wyniósł 19\%, a w rynku depozytów - 21\% (tab. 4). Do krajów, w których w 2012 r. wartość kredytów udzielonych przez banki spółdzielcze miała co najmniej kilkunastoprocentowy udział w rynku, można zaliczyć: Austrię (Osterreichische Raiffeisenbanken), Cypr, Finlandię, Francję, Niemcy, Włochy (AssocNazionale fra le Banche Popolari), Holandię i Szwajcarię. W tych samych krajach udział w rynku depozytów był również co najmniej kilkunastoprocentowy. Wzrost udziału kredytów w rynku oraz w rynku depozytów w analizowanym okresie dotyczył większości analizowanych grup spółdzielczych. Ważnym klientem dla banków spółdzielczych w Europie są małe i średnie przedsiębiorstwa. Wynika to głównie z dobrego dopasowania specyfiki banków spółdzielczych do uwarunkowań, w jakich działają tego typu podmioty oraz rozumienia ich potrzeb ${ }^{13}$. Istniejące dane dla połowy bankowych grup spółdzielczych wskazują, że większość z nich ma istotny udział $w$ finansowaniu potrzeb przedsiębiorstw z grupy MSP, sięgający nawet ponad 40\% (Holandia). Są też jednak takie kraje (jak Portugalia, Węgry czy Wielka Brytania), gdzie udział ten jest niewielki, sięgający kilku procent w rynku.

\footnotetext{
${ }^{13}$ A. Gospodarowicz, op. cit., s. 260.
} 
Tabela 4. Udział w rynku depozytów, kredytów, w tym dla mikro-, małych i średnich przedsiębiorstw (MŚP), bankowych grup spółdzielczych w Europie w latach 2007-2012 (\%)

\begin{tabular}{|c|c|c|c|c|c|c|c|c|c|}
\hline \multirow{2}{*}{$\begin{array}{l}\mathrm{Nr} \\
\text { grupy }\end{array}$} & \multicolumn{3}{|c|}{ Udział w rynku depozytów } & \multicolumn{3}{|c|}{ Udział w rynku kredytów } & \multicolumn{3}{|c|}{$\begin{array}{l}\text { Udział w rynku kredytów dla } \\
\text { MŚP }\end{array}$} \\
\hline & 2007 & 2010 & 2012 & 2007 & 2010 & 2012 & 2007 & 2010 & 2012 \\
\hline 1 & 27,80 & 29,3 & 29,80 & 23,80 & 25,5 & 26,10 & - & 39,00 & 37,00 \\
\hline 2 & 8,00 & 7,2 & 7,20 & 7,50 & 7,3 & 6,40 & - & 7,40 & 6,50 \\
\hline 3 & 2,60 & 4,10 & 2,90 & 2,40 & 2,26 & 5,00 & - & - & - \\
\hline 4 & 20,00 & 19,34 & 21,60 & 22,00 & 20,35 & 19,20 & - & - & - \\
\hline 5 & - & 0,62 & 4,40 & - & 0,51 & 3,10 & - & 0,50 & - \\
\hline 6 & 32,30 & 32,5 & 34,10 & 31,10 & 33,0 & 33,40 & - & - & - \\
\hline 7 & 29,00 & & 23,40 & 25,00 & - & 20,60 & 28,00 & 25,00 & 26,40 \\
\hline 8 & 17,30 & 14,2 & 15,00 & 12,70 & 17,00 & 17,10 & 16,00 & 15,80 & 14,50 \\
\hline 9 & 6,70 & 6,7 & - & 7,60 & 7,6 & - & 8,00 & - & - \\
\hline 10 & 18,30 & 19,4 & 19,80 & 16,00 & 16,9 & 18,30 & 25,00 & 27,90 & 30,30 \\
\hline 11 & 0,80 & 1,0 & 1,80 & 1,00 & 1,0 & 1,30 & - & & 15,00 \\
\hline 12 & 9,10 & 8,58 & 8,70 & 3,10 & 2,77 & 4,40 & 4,00 & 7,80 & 8,70 \\
\hline 13 & 24,60 & 26,9 & 26,90 & 22,50 & 24,7 & 24,70 & 23,00 & 27,40 & 15,00 \\
\hline 14 & 9,10 & 7,3 & 7,40 & 7,00 & 7,2 & 7,10 & 17,00 & - & - \\
\hline 15 & 10,00 & 11,0 & - & 10,00 & 11,0 & - & 6,00 & 8,00 & - \\
\hline 16 & 1,40 & 2,0 & 4,60 & 0,80 & 1,0 & 6,80 & - & - & - \\
\hline 17 & 41,00 & 40,0 & 39,00 & 28,00 & 29,00 & 31,00 & 38,00 & 43,00 & 43,00 \\
\hline 18 & 8,80 & 8,90 & 9,40 & 6,50 & 5,70 & 7,70 & 13,00 & 14,00 & 20,00 \\
\hline 19 & 5,50 & 4,50 & 4,50 & 3,20 & 3,10 & 3,70 & - & 5,00 & 5,50 \\
\hline 20 & 1,00 & - & - & 0,70 & - & - & - & - & - \\
\hline 21 & 1,80 & 2,67 & 2,80 & 1,70 & 1,64 & 1,60 & - & - & - \\
\hline 22 & 5,00 & 6,62 & 6,70 & 5,20 & 5,26 & 5,80 & - & - & - \\
\hline 23 & - & - & - & - & - & - & - & - & - \\
\hline 24 & 1,00 & 5,0 & - & 3,00 & 1,5 & 3,00 & 2,00 & 0,60 & 0,40 \\
\hline 25 & 21,00 & 21,00 & - & 18,00 & 19,00 & - & 25,00 & - & - \\
\hline 26 & 18,60 & - & 20,00 & 12,10 & & 16,10 & - & - & - \\
\hline
\end{tabular}

- brak danych

Źródło: opracowanie własne na podstawie danych EACB: Key Statistics of European Association of Co-operative Banks (EACB) [2015], http://www.eacb.coop/en/home.html (dostęp: 20.04.2015).

Praktycznie we wszystkich analizowanych bankowych grupach efektywność wykorzystania majątku mierzona jego rentownością (ROA, return on assets) była dość niska, nieprzekraczająca $1 \%$. Jedynie w Polsce przez cały analizowany okres przekraczała $1 \%$, co jest pozytywnym zjawiskiem ${ }^{14}$.

\footnotetext{
${ }^{14}$ A. Kopiński, Analiza finansowa banku, PWE, Warszawa 2008, s. 154.
} 
Tabela 5. Wskaźniki finansowe bankowych grup spółdzielczych w Europie w latach 2007-2012 (\%)

\begin{tabular}{|c|c|c|c|c|c|c|c|c|c|c|c|c|}
\hline \multirow{2}{*}{$\begin{array}{c}\mathrm{Nr} \\
\text { grupy }\end{array}$} & \multicolumn{3}{|c|}{ ROA } & \multicolumn{3}{|c|}{ ROE } & \multicolumn{3}{|c|}{ Koszt/dochód (C/I) } & \multicolumn{3}{|c|}{$\begin{array}{l}\text { Współczynnik } \\
\text { wypłacalności }\end{array}$} \\
\hline & 2007 & 2010 & 2012 & 2007 & 2010 & 2012 & 2007 & 2010 & 2012 & 2007 & 2010 & 2012 \\
\hline 1 & 0,6 & 0,6 & 0,4 & 18,4 & 10,5 & 5,8 & 66,0 & 65,7 & 90,3 & 10,6 & 11,4 & 11,5 \\
\hline 2 & 0,5 & 0,3 & $-0,2$ & 11,3 & 5,1 & $-3,7$ & 63,0 & 62,5 & 66,0 & 11,9 & 17,0 & 14,2 \\
\hline 3 & 1, & 1,1 & 0 & 14,1 & 8,6 & 3,0 & 67,0 & 73,4 & 84,4 & 18,1 & 13,5 & 15,1 \\
\hline 4 & 0,9 & 0,7 & & 26,2 & 13,4 & & 82,0 & 54,5 & 51,8 & 45,0 & 5,0 & 5,6 \\
\hline 5 & - & $-1,2$ & 0,2 & - & $12, \overline{1}$ & 4,6 & - & 128,0 & 56,6 & - & 12,1 & 19,1 \\
\hline 6 & 1,2 & 0,5 & & 13,7 & 6,8 & 7,0 & 50,0 & 59,0 & 63,0 & 13,8 & 12,8 & 14,1 \\
\hline 7 & 0,4 & - & - & 12,2 & - & - & 68,0 & 60,9 & 65,8 & 9,6 & 11,7 & 14,0 \\
\hline 8 & 0,5 & 0,5 & & 11,4 & 11,9 & 5,8 & 62,0 & 60,8 & & 11,0 & 4,7 & 14,5 \\
\hline 9 & 0,3 & 0,3 & - & 5,8 & 5,8 & - & 79,0 & 78,5 & - & 11,1 & 11,1 & - \\
\hline 10 & 0,4 & 0 & & 6,9 & 13,0 & 13,5 & 69,0 & 63,3 & 61,2 & 12,3 & 13,7 & 14,7 \\
\hline 11 & - & 0,7 & $-0,7$ & - & 5,6 & $-6,1$ & - & - & - & - & 9,9 & 10,9 \\
\hline 12 & 0,8 & 0 & & 11,0 & 8,6 & 6,5 & 76,0 & 68,8 & 72,2 & 7,9 & 20,8 & 7,1 \\
\hline 13 & 0,9 & 0 , & & 10,1 & 5,1 & & 54,0 & 57,6 & 57,6 & 10,4 & 11,2 & 11,2 \\
\hline 14 & 0,9 & 0 & & 9,4 & 1,7 & 2,4 & 58,0 & 74,2 & 60,3 & 15,3 & 15,2 & 15,0 \\
\hline 15 & 0,3 & & & 7,4 & 8,0 & 15,4 & 67,0 & 71,2 & & 8,3 & 9,7 & 9,6 \\
\hline 16 & 0,5 & $-3,3$ & & 4,2 & $-0,4$ & 0,2 & - & - & 99,6 & 16,6 & 19,2 & 20,2 \\
\hline 17 & 0,5 & & & & & & 67, & 64,5 & & 10,9 & 5,2 & 19,0 \\
\hline 18 & 1,5 & 1,1 & 1,4 & 17,2 & 12,1 & 12,8 & 35,0 & 69,2 & 63,5 & 13,8 & 13,6 & 13,8 \\
\hline 19 & 1,1 & & & & & & 54,0 & 67,2 & & 14,4 & 13,4 & 10,9 \\
\hline 20 & - & 0,7 & 0,6 & - & 3,2 & 2,8 & - & 97,1 & 97,2 & - & 21,8 & 22,2 \\
\hline 21 & 1,4 & & & & 0,5 & 11,6 & 66,0 & 76,8 & 82,9 & 14,3 & 13,4 & 11,9 \\
\hline 22 & 0,8 & 0,4 & $-1,2$ & & 4,6 & & - & 52,8 & 49,3 & - & - & - \\
\hline 23 & - & - & - & - & - & - & - & - & - & - & - & - \\
\hline 24 & 0,1 & 0,2 & 0,4 & 0,8 & 3,8 & 9,8 & 65,0 & 71,6 & 74,3 & 5,4 & 4,6 & 3,4 \\
\hline 25 & 0,5 & - & - & 10,4 & - & - & 65,3 & - & - & 11,0 & - & - \\
\hline 26 & - & - & - & - & - & 6,2 & - & - & 65,8 & - & - & 12,9 \\
\hline
\end{tabular}

- brak danych

Źródło: opracowanie własne na podstawie danych EACB: Key Statistics of European Association of Co-operative Banks (EACB) [2015], http://www.eacb.coop/en/home.html (dostęp: 20.04.2015).

W 2012 r. trzy grupy odnotowały deficytowość (z Austrii, Grecji, Hiszpanii). Rentowność kapitału własnego (ROE, return on equity) badanych grup bankowych wahała się od kilku do kilkunastu procent. W 2012 r. najwyższą efektywność kapitału własnego zanotowały: Luksemburg $(15,4 \%)$, Niemcy $(13,5 \%)$, Polska $(12,8 \%)$ i Słowenia $(11,6 \%)$. Porównując rok 2007 i 2012, można stwierdzić, że jedynie w Niemczech, Luksemburgu i Wielkiej Brytanii wzrosły wartości obu wskaźników rentowności. Wskaźnik kosztów do dochodów (C/I, cost/income) pokazuje relację kosztów operacyjnych (działania banku, to jest jego funkcjonowania ${ }^{15}$ ) do wyniku na działalności bankowej (głównie z tytułu uzy-

15 Ibidem, s. 106. 
skanych prowizji i odsetek). Do grupy krajów o najkorzystniejszej, czyli najmniejszej, wspomnianej relacji (< 60\%) w 2012 r. należały: Cypr, Dania, Włochy i Hiszpania. Poprawa tego wskaźnika w latach 2007-2012 nastąpiła tylko w kilku analizowanych krajach (Cypr, Francja, Niemcy, Węgry, Luksemburg, Holandia). Wartość współczynnika wypłacalności w 2012 r. w większości grup bankowych (poza Cyprem, Węgrami i Wielką Brytanią) była na poziomie wymaganym przez prawo (8\%). Wskaźnik ten służy ocenie adekwatności kapitałowej banku, jego bezpieczeństwa. Adekwatność kapitałowa to wymóg posiadania przez bank kapitałów własnych odpowiadających rozmiarom prowadzonej działalności i ponoszonemu ryzyku. Spełnianie wymogów adekwatności kapitałowej ma na celu zapewnianie bezpieczeństwa powierzonych bankom środków. Jest to stosunek funduszy własnych netto (pomniejszonych o pewne elementy) do aktywów i pozycji pozabilansowych ważonych ryzykiem (kredytowym, operacyjnym i rynkowym) ${ }^{16}$. Za pozytywne należy uznać, że tylko kilka grup bankowych w okresie 2007-2012 zanotowała spadek (i to niewielki) tego wskaźnika.

\section{PODSUMOWANIE}

Sektor bankowości spółdzielczej w Europie zajmuje ważną pozycję w systemie bankowym, choć jego rozwój organizacyjno-ekonomiczny w poszczególnych krajach jest zróżnicowany.

Liczba banków spółdzielczych w UE27 w latach 2007-2012 zmniejszyła się o 11\% (do 3,7 tys.) przy wzroście liczby placówek o $13 \%$ (do prawie 71 tys.). Wzrost liczby placówek bankowych przy spadku lub stagnacji liczby banków spółdzielczych wystąpił w dziewięciu krajach, a tylko w dwóch przy ich jednoczesnym wzroście (Banques Populaires z Francji i Assoc. Nazionale fra le Banche Popolari z Włoch). Do krajów europejskich o największej liczbie placówek banków spółdzielczych w 2012 r. (to jest 90\% wszystkich w UE) można zaliczyć: Francję, Niemcy, Austrię, Włochy, Hiszpanię, Polskę. Gęstą siecią placówek bankowych dysponują zatem kraje zarówno o wysokiej, jak i niskiej (Francja i Hiszpania) liczbie banków spółdzielczych.

W 2012 r. w UE członków banków spółdzielczych było prawie $56 \mathrm{mln}$, to jest o $13 \%$ więcej niż 4 lata wcześniej. Jedynie w kilku krajach (jak Węgry, Polska, Rumunia, Słowenia, Wielka Brytania) odnotowano spadek liczby członków banków spółdzielni. Najwięcej takich członków w 2012 r. było we Francji, w Niemczech, Austrii, we Włoszech, w Hiszpanii, Wielkiej Brytanii, Holandii, Szwajcarii, Finlandii i Polsce. W krajach o dużej liczbie członków banków spółdzielczych odnotowano także najwięcej klientów tych banków. Ogółem było ich w UE w 2012 r. 214,7 mln osób, czyli o ponad 1/3 więcej niż w 2007 r. W kilku krajach liczba klientów banków spółdzielczych spadła lub się nie zmieniła (Austria, Polska, Portugalia, Rumunia, Słowenia, Niemcy). Liczba klientów banków spółdzielczych w UE przewyższała liczbę ich członków. Relacja ta wzrosła w badanym okresie z 3,2 do 3,8. W latach 2007-2012 zatrudnienie w omawianym sektorze banków w UE wzrosło o 13\% (do 847 tys. osób). Najwięcej zatrudnionych osób w tym sektorze w 2012 r. było we Francji, Niemczech, Włoszech, Holandii, Austrii, Polsce i Hiszpanii.

W latach 2007-2012 w europejskich bankach spółdzielczych wartość posiadanego majątku wzrosła o 42\% (do 7,3 bln euro). Można zaobserwować koncentrację majątku oma-

\footnotetext{
${ }^{16}$ M. Iwanicz-Drozdowska, Zarządzanie finansowe bankiem, PWE, Warszawa 2005, s. 135-144.
} 
wianego sektora bankowego w kilku krajach, ponieważ 91\% aktywów bankowości spółdzielczej UE znajdowało się we Francji, Niemczech, Holandii, Włoszech i Austrii. Prawie wszystkie grupy spółdzielcze (poza jedną z Austrii) systematycznie zwiększały wartość posiadanych aktywów. W porównaniu z tempem wzrostu majątku wartość udzielonych kredytów przez banki spółdzielcze wzrosła w szybszym tempie (o 47,6\%). Wartość kredytów w 2012 r. w UE wyniosła ponad 4 bln euro. Największy udział w tej kwocie miały banki z Francji (44,5\%), Niemiec (15,6\%), Włoch (13,2\%) i Holandii (11,3\%). Większość banków zwiększyła akcję kredytową (poza Słowenią, Hiszpanią i jedną grupą bankową z Austrii). Podstawą rosnącej akcji kredytowej była zwiększona baza depozytowa w omawianym sektorze UE (o 51,5\% do ponad 4 bln euro). Prawie połowa $(48,8 \%$ ) tej kwoty przypadała na Francję, 16,3\% na Niemcy, $13,9 \%$ na Włochy, a 8,2\% na Holandię. Prawie we wszystkich krajach wzrosła baza depozytowa. W całej UE wzrosła relacja depozytów do kredytów z 0,98 do 1,01, co oznacza, że w 2012 r. powstała rezerwa do udzielania kredytów z przyjętych depozytów. Taka sytuacja dotyczyła w 2012 r. 14 grup bankowych, wśród nich w dziewięciu przypadkach zjawisko osłabło w porównaniu z rokiem 2007.

Banki spółdzielcze miały w niektórych krajach istotny udział w rynku kredytów i depozytów. Do krajów, w których w 2012 r. wartość kredytów udzielonych przez banki spółdzielcze miała co najmniej kilkunastoprocentowy udział w rynku, można zaliczyć: Austrię (Osterreichische Raiffeisenbanken), Cypr, Finlandię, Francję, Niemcy, Włochy (Assoc. Nazionale fra le Banche Popolari), Holandię i Szwajcarię. Wzrost udziału kredytów w rynku oraz w rynku depozytów w analizowanym okresie dotyczył większości analizowanych grup spółdzielczych. W niektórych krajach ważnym partnerem banków spółdzielczych był sektor małych i średnich przedsiębiorstw, dla których udzielone kredyty sięgały nawet kilkudziesięciu procent w rynku.

Praktycznie we wszystkich bankowych grupach efektywność wykorzystania majątku mierzona jego rentownością (ROA) była dość niska i nie przekraczała 1\%. Rentowność ich kapitału własnego (ROE) wahała się od kilku do kilkunastu procent. Jedynie w Niemczech, Luksemburgu i Wielkiej Brytanii wzrosły wartości obu wskaźników rentowności w badanym okresie. Tylko kilka grup bankowych poprawiło relację kosztów do dochodów. Najkorzystniejszą relację $(<60 \%)$ w 2012 r. odnotowały: Cypr, Dania, Włochy i Hiszpania. Wartość współczynnika wypłacalności w 2012 r. w większości grup bankowych (poza Cyprem, Węgrami i Wielką Brytanią) była na poziomie wymaganym przez prawo bankowe $(8 \%)$. Za pozytywne należy uznać, że tylko kilka grup bankowych w okresie 2007-2012 zanotowało spadek (i to niewielki) tego wskaźnika.

\section{LITERATURA}

[1] Dobosiewicz Z., Bankowość, PWE, Warszawa 2011.

[2] Dziekański P., Banki spółdzielcze inkubatorami lokalnej przedsiębiorczości, [w:] Bank spótdzielczy gwarantem stabilizacji $i$ bezpieczeństwa lokalnego systemu finansowego, red. A. Pawlik, P. Dziekański, Uniwersytet Jana Kochanowskiego, Kielce 2012.

[3] Gospodarowicz A., Funkcjonowanie spótdzielczych grup bankowych w Polsce i wybranych krajach europejskich, Wydawnictwo Uniwersytetu Ekonomicznego we Wrocławiu, Wrocław 2008.

[4] Golec M., Społeczne uwarunkowania działalności banków spótdzielczych, [w:] Banki spótdzielcze $w$ Polsce $w$ warunkach kryzysu finansowego i gospodarczego, red. M. Stefański, WSH-E, Włocławek 2010.

[5] Iwanicz-Drozdowska M., Zarzadzanie finansowe bankiem, PWE, Warszawa 2005. 
[6] Kata R., Rola banków spółdzielczych w finansowaniu rolnictwa regionu podkarpackiego, FOSZE, Rzeszów 2003.

[7] Key Statistics of European Association of Co-operative Banks (EACB) [2015], http://www.eacb.coop/en/home.html (dostęp: 20.04.2015).

[8] Kopiński A., Analiza finansowa banku, PWE, Warszawa 2008.

[9] Magdoń A., Systemic and structural transformations of cooperative banking in Poland, Wydawnictwo Katolickiego Uniwersytetu Lubelskiego Jana Pawła II, Stalowa Wola 2009.

[10] McCarroll V., Habberfield S., The outlook for co-operative banking in Europe 2012. Banking on values, building on agility, Oliver Wyman Report, http://www.oliverwyman.com/theoutlook-for-cooperative-banking-in-europe-2012.htm\#.UeaGTW0SqZR (dostęp: 20.04.2015).

[11] Miklaszewska E., Bank na rynku finansowym. Problemy skali, efektywności i nadzoru, Wolters Kluwer, Warszawa 2010.

[12] Siudek T., Wptyw działalności kredytowej banków spółdzielczych na lokalny rozwój społeczno-gospodarczy w Polsce, [w:] Bank spótdzielczy gwarantem stabilizacji i bezpieczénstwa lokalnego systemu finansowego, red. A. Pawlik, P. Dziekański, Uniwersytet Jana Kochanowskiego, Kielce 2012.

[13] Szambelańczyk J., Banki spótdzielcze w Polsce w procesach zmian systemowych, Wydawnictwo Akademii Ekonomicznej w Poznaniu, Poznań 2006.

[14] Szyszko M., Banki spótdzielcze, [w:] Pośrednictwo finansowe, W. red. PrzybylskaKapuścińska, CeDeWu, Warszawa 2009.

[15] Szelągowska A., Wspótczesna bankowość spótdzielcza, CeDeWu, Warszawa 2012.

[16] Zuba M., Zmiany działalności kredytowej banków spótdzielczych $w$ Polsce $i$ w Europie w latach 2007-2011, ,Zeszyty Naukowe SGGW w Warszawie, Ekonomika i Organizacja Gospodarki żywnościowej” 2013/103.

\section{ANALYSIS AND EVALUATION OF COOPERATIVE BANKING DEVELOPMENT IN POLAND AND CHOSEN EUROPEAN COUNTRIES IN THE YEARS 2007-2012}

The aim of the paper was the evaluation of changes in the activity of selected cooperative bank groups in Europe in the period 2007-2012. The data used in the study are derived from 26 selected banking cooperative groups in Europe ( 25 from EU countries and 1 from Switzerland), that were the members of European Association of co-operative Banks (EACB). The development of cooperative banking, which can be seen from the of the organization and financial point of view, was dissimilar in each country. In general, in the EU as a whole there was an organizational development in this sector, as it is demonstrated by the growing number of bank offices, the number their members and clients and the number of employees. The cooperative banks strengthen their financial position, because they increased the value of their assets, including loans and acquired deposits. The asset efficiency measured by its profitability (ROA) was quite low in all the groups of bank, lower than $1 \%$. In the year 2012 three groups reported losses. The return on equity (ROE) varied from a few to a dozen percent. In the years 2007-2012 the improvement of the revenue cost index occurred only in a few countries. The value of the solvency ratio was at the level required by law $(8 \%)$ in the most of banking groups in the year 2012. Only a few banking groups recorded a decrease (and a small one) of this ratio in the period 2007-2012.

Keywords: co-operative banks, profitability, solvency

DOI: 10.7862/rz.2015.mmr.30

Tekst złożono w redakcji: maj 2015

Przyjęto do druku: lipiec 2015 